\title{
The Nosology of the Spinal Muscular Atrophies
}

\author{
ALAN E. H. EMERY
}

\author{
From the University Department of Human Genetics, Western General Hospital, Edinburgh
}

In the last few years there has been an increase in interest among neurologists and geneticists in the spinal muscular atrophies. With the advent of several relatively sophisticated diagnostic procedures many patients once thought to be suffering from muscular dystrophy have in fact been found to have spinal muscular atrophy.

The spinal muscular atrophies may be defined as a group of inherited diseases in which there is degeneration of the anterior horn cells (lower motor neurones) of the spinal cord and often the bulbar motor nuclei, but with no evidence of pyramidal tract involvement. When so defined, motor neurone disease (progressive bulbar palsy, progressive muscular atrophy, and amyotrophic lateral sclerosis) and its variants and the various forms of amyotrophy are excluded as are congenital abnormalities of the spinal cord, and traumatic, toxic, infective, and neoplastic causes of anterior horn cell degeneration.

Early literature on the spinal muscular atrophies has been extensively reviewed by Wiesendanger (1962); Smith and Patel (1965); HausmanowaPetrusewicz (1970); and Namba, Aberfeld, and Grob (1970). The frequency of all forms of spinal muscular atrophy is at least 1 in 20,000 (Brandt, 1950a) and possibly very much more. The 'wobbler' mutant of mouse is a possible analogue (Duchen, Strich, and Falconer, 1968).

The main clinical features of spinal muscular atrophy are wasting and weakness of muscles supplied by the affected anterior horn cells. Necropsy confirmation of degeneration and loss of anterior horn cells has been reported both in severe (Brandt, 1950a) and more benign (Kohn, 1968; Namba et al, 1970) forms of spinal muscular atrophy.

It is essential to recognize the heterogeneity among the spinal muscular atrophies when giving a prognosis and for genetic counselling. Unfortunately early attempts to classify them were largely unsatisfactory for two reasons. Firstly, because such classifications were often based on clinical features

Received 13 April 1971. alone, insufficient importance being given to genetic differences. Secondly, because of confusion with primary muscle diseases. Only in recent years, with the aid of more refined diagnostic procedures, has it been possible to make a clear distinction between these two groups of disorders. For these reasons in the following discussion evidence will be largely drawn from more recent publications.

Some investigators have been attracted by the idea of a spectrum of clinical variation in spinal muscular atrophy ranging from the severe infantile to the benign adult forms. Some have even included certain neuropathies in this 'spectrum'. This concept however is unhelpful and if anything hinders the investigation of genetic heterogeneity.

\section{Aetiology}

The majority of cases of spinal muscular atrophy are clearly inherited. However, there have been frequent reports of the onset of symptoms following an infection (viral or bacterial) or an inoculation or vaccination (Brandt, 1950a; Wohlfart, Fex, and Eliasson, 1955; Dubowitz, 1964; Gardner-Medwin, Hudgson, and Walton, 1967; Meadows, Marsden, and Harriman, 1969a). Since in several of these reports there were other similarly affected relatives, it seems likely that clinical manifestations were precipitated rather than caused by the particular episode in question, but whether this or the subsequent bed rest was the precipitating factor is not clear. Certainly, following bed rest, symptoms may be made much worse (eg, case 10 in GardnerMedwin et al, 1967).

Case Report. We have studied a patient with scapuloperoneal muscular atrophy in whom muscle weakness was first noticed at age 35 after 10 days bed rest with a swollen and painful leg following a smallpox vaccination. This man has an affected cousin in whom muscle weakness developed insidiously, the onset of which was not clearly associated with any particular exogenous factor.

An apparent increase in the incidence of sporadic cases of infantile spinal muscular atrophy (Werdnig- 
Hoffman disease) in the region of Freiburg, West Germany, in recent years has been observed by Beckmann, Manz, and Moser (1970). These investigators attributed this to the more widespread use of oral poliomyelitis vaccine and the possibility of infection in utero by poliomyelitis virus. Poliomyelitis was first implicated as a possible causative factor in spinal muscular atrophy by Marburg in 1912. However, experimental evidence concerning RNA metabolism in degenerating motor neurones in infantile spinal muscular atrophy, does not support the idea of infection with an RNA virus such as poliomyelitis (Hogenhuis, Spaulding, and Engel, 1967). The nature of the underlying genetic abnormality is unknown.

\section{Diagnosis}

Clinical Presentation. The distribution of muscle wasting and weakness is different in different spinal muscular atrophies, and the weakness is frequently associated with muscle fasciculations. Benign spontaneous fasciculation, however, is not uncommon in normal individuals especially in the calf or small hand muscles. It cannot be distinguished with certainty from the pathological type but fasciculation which is seen only after movement or strong contraction and is not associated with muscle weakness is usually benign (Gardner-Medwin and Walton, 1969). Fasciculations are rarely seen in primary muscle disease. In spinal muscular atrophy they are indicative of anterior horn-cell degeneration and may be seen in the limb musculature and/or the tongue.

Electromyography. Electromyographic (EMG) evidence of anterior horn cell degeneration, with loss of corresponding motor units, includes spontaneous, regular motor unit activity (fibrillation or fasciculation potentials), and 'giant' action potentials (high amplitude and long duration) with reduced interference pattern on voluntary contraction of the muscle (Lambert, 1963; Amick, Smith, and Johnson, 1966; Gardner-Medwin et al, 1967; Hausmanowa-Petrusewicz et al, 1968; Meadows et al, 1969a and b). These large action potentials may be partly due to hypertrophy of remaining muscle fibres. It is more likely, however, that the main factor is either the synchronous firing of surviving motor units with summation of motor unit potentials (Buchthal and Olsen, 1970), or the synchronous firing of the normal motor unit plus the muscle fibres which, due to collateral re-innervation, come to share the same motor nerve (see Brown and Johns, 1970). In general the EMG findings in the various spinal muscular atrophies $\stackrel{\overrightarrow{0}}{2}$ are very similar, though it has been reported that $\delta$ there are differences between the infantile and $\stackrel{\Phi}{\oplus}$ juvenile forms (Buchthal and Olsen, 1970). The $\stackrel{+}{+}$ EMG has occasionally been found to be normal or even myopathic (Walton, 1970). Motor nerve conduction velocity is normal.

Muscle Histology with conventional stains reveals atrophy of groups of fibres (group atrophy) supplied by the affected anterior horn cells (Pearce and Harriman, 1966; Gardner-Medwin et al, 1967; Hausmanowa-Petrusewicz et al, 1968; Meadows et $a l$, 1969a and b; Munsat et al, 1969; Buchthal and Olsen, 1970; Engel, 1970). Group atrophy is pathognomic of spinal muscular atrophy (Fig. 1). The atrophy may be so profound as to present the appearance of 'nuclear clumps'. The adjacent fibres may appear more-or-less normal or have undergone changes similar to those seen in myopathy (Fig. 2); there may be variations in fibre size-some fibres being hypertrophic, rounding of fibres, central nuclei and even occasionally fibre necrosis with phagocytosis (Mumenthaler, 1970). In long-standing cases the muscle tissue may be largely replaced by fat and connective tissue. In the very early stages of the disease, however, the only abnormality may be 'scattered atrophy' (Fige 1): scattered small angular fibres wedged betweeg normal looking fibres (Engel, 1970). Thus, the histological appearances in the early stages of the disease may be easily misdiagnosed as normal or as myopathic in the later stages of the disease.

The apparent myopathic changes in neurogenic atrophy may be due to reinnervation by neighbouring healthy motor neurones (Meadows et al, 1969a). Drachman et al (1967) found that in muscle biopsies from patients who had suffered from poliomyelitis 10 to 54 years previously, features classically found in myopathy were present. They suggested that work hypertrophy and partial re-innervation of atrophic fibres could be responsible for variation in fibre size, and that later degenerative changes might be due to defective re-innervation. Phagocytosis and endomysial fibrosis are merely reponses to fibre degeneration.

Muscle Histochemistry. Histochemical studies, using such enzyme stains as ATPase, NAD diaphorase, and phosphorylase, have shown that muscle fibres in human skeletal muscle can be differentiated into two types: type I fibres which predominate in slow muscles (eg, soleus) are rich in oxidative enzymes but poor in phosphorylase activity whereas the reverse is true of type II fibres 

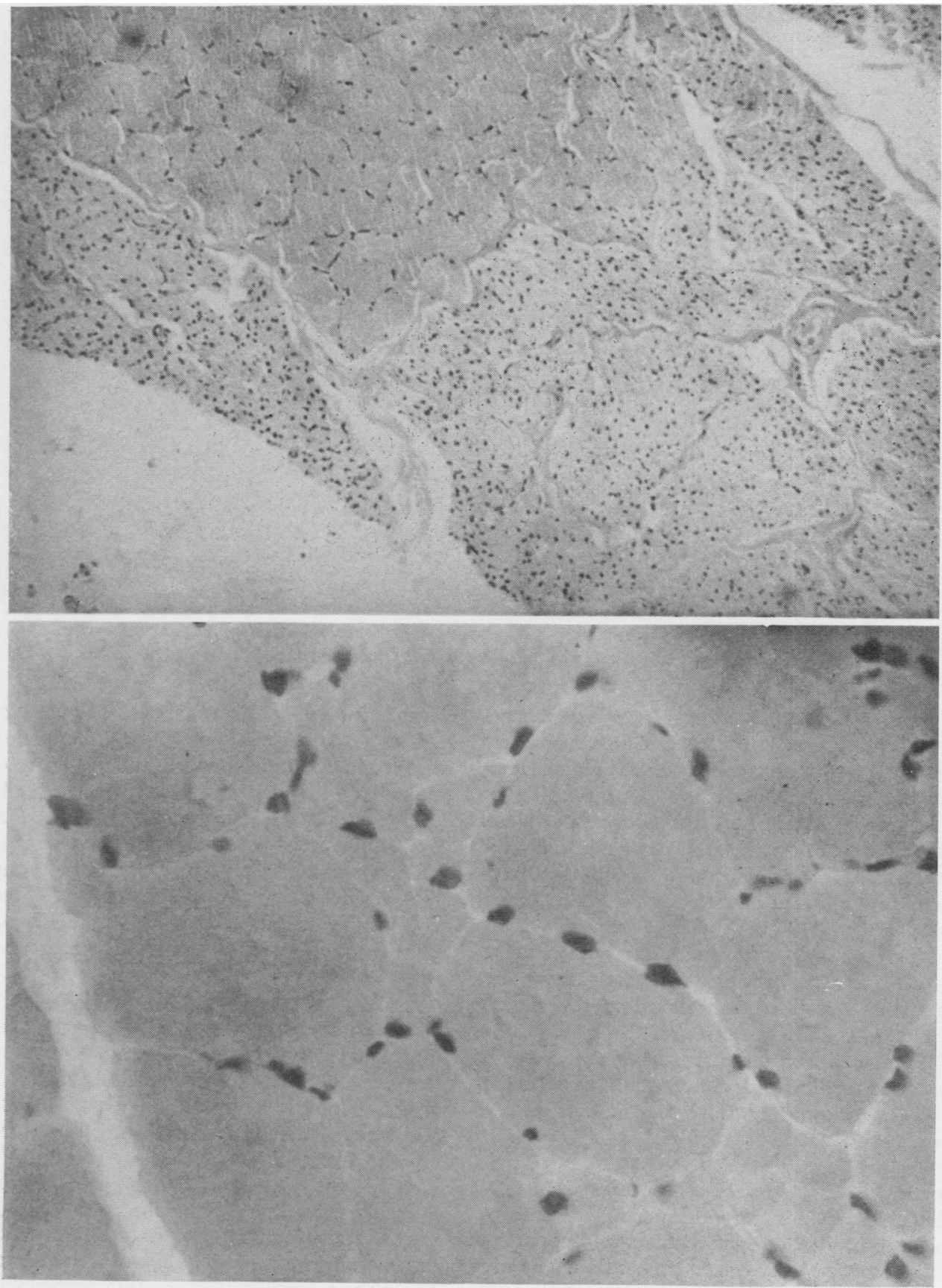

Fig. 1. Muscle fibre atrophy in spinal muscular atrophy.

Above: large groups of atrophic fibres (haematoxylin and eosin; original $\times 200$.)

Below: small group of atrophic fibres (Gomori trichrome; original $\times 400$.)

Quadriceps muscle, juvenile spinal muscular atrophy. 


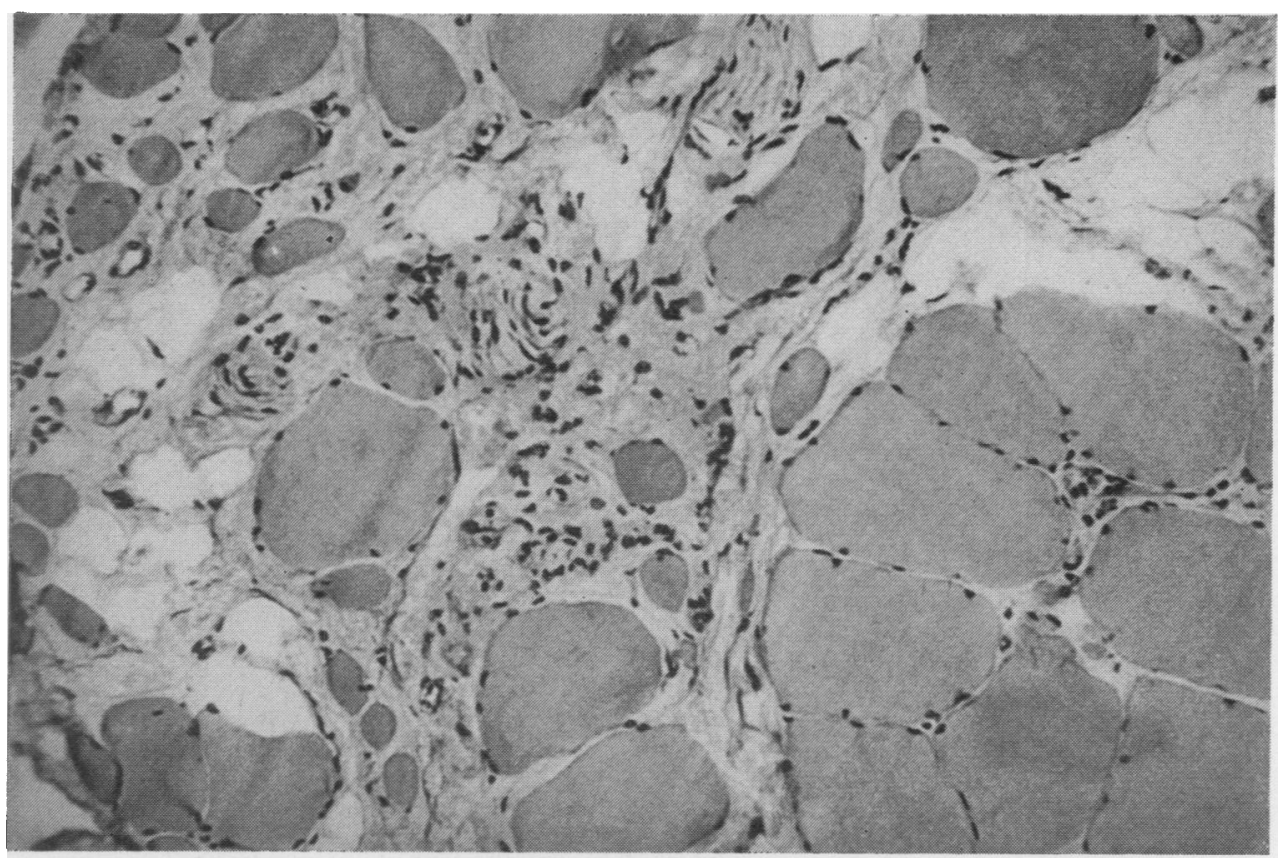

FIG. 2. Myopathic changes in spinal muscular atrophy. Note the variation in fibre size, rounding of muscle fibres, and fibre necrosis. Deltoid muscle, scapuloperoneal spinal muscular atrophy (haematoxylin and eosin; original $\times 200$.)

which predominate in fast muscle (eg, gastrocnemius). Normal muscle presents a mosaic pattern of type I and type II fibres (Fig. 3) but in neurogenic atrophy there is a tendency for 'type grouping' to occur ie, the grouping of fibres of a particular histochemical type (I or II). It has been suggested that these findings could be due to collateral reinnervation of affected fibres by normal motor neurones (Engel, 1970).

In long-standing neurogenic atrophy 'target fibres' (concentric zones of enzyme activity extending the length of the fibre) are found in the muscle (Engel, 1961). These resemble the so-called 'cores' seen in rabbit muscle during the phase of reinnervation following denervation (Dubowitz, 1967) and are similar to those seen in central core disease (Dubowitz and Roy, 1970).

Muscle Innervation. Perhaps one of the most useful techniques for diagnosing neurogenic atrophy is the intravital or supravital staining of motor nerve filaments and end-plates with methylene blue (Coërs and Woolf, 1959). In neurogenic atrophy (Fig. 4) there is branching of subterminal intramuscular nerve fibres (rarely seen in normal muscle) with collateral reinnervation, and degeneration of end-plates (Amick et al, 1966; Pearce and
Harriman, 1966; Hausmanowa-Petrusewicz et al, 1968). Branching of nerve fibres seems to be more profuse in the more benign juvenile form of spinal muscular atrophy than in the infantile form (Hausmanowa-Petrusewicz et al, 1968). A histological diagnosis of denervation is only possible when there is either group atrophy or branching of subterminal nerve fibres. The latter is particularly useful in cases where routine histology is normal or if 'myopathic' features alone are present (Meadows et al, 1969a).

Other Investigations. The diagnosis of spinal muscular atrophy can be made on the clinical features, EMG findings, muscle histology, and the study of muscle innervation. Other investigations add little further information. The serum level of creatine kinase is raised in a proportion of patients, usually with the more benign forms of spinal muscular atrophy (Hetnarska, Prot, and Sawicka, 1968), and is commonly only slightly raised but occasionally may be up to 20 times the normal value. Since the serum level of creatine kinase may also be elevated in various myopathies (Dreyfus and Schapira, 1962) it is of little diagnostic value.

In the Duchenne type of muscular dystrophy the electrocardiogram (ECG) is frequently abnormal 

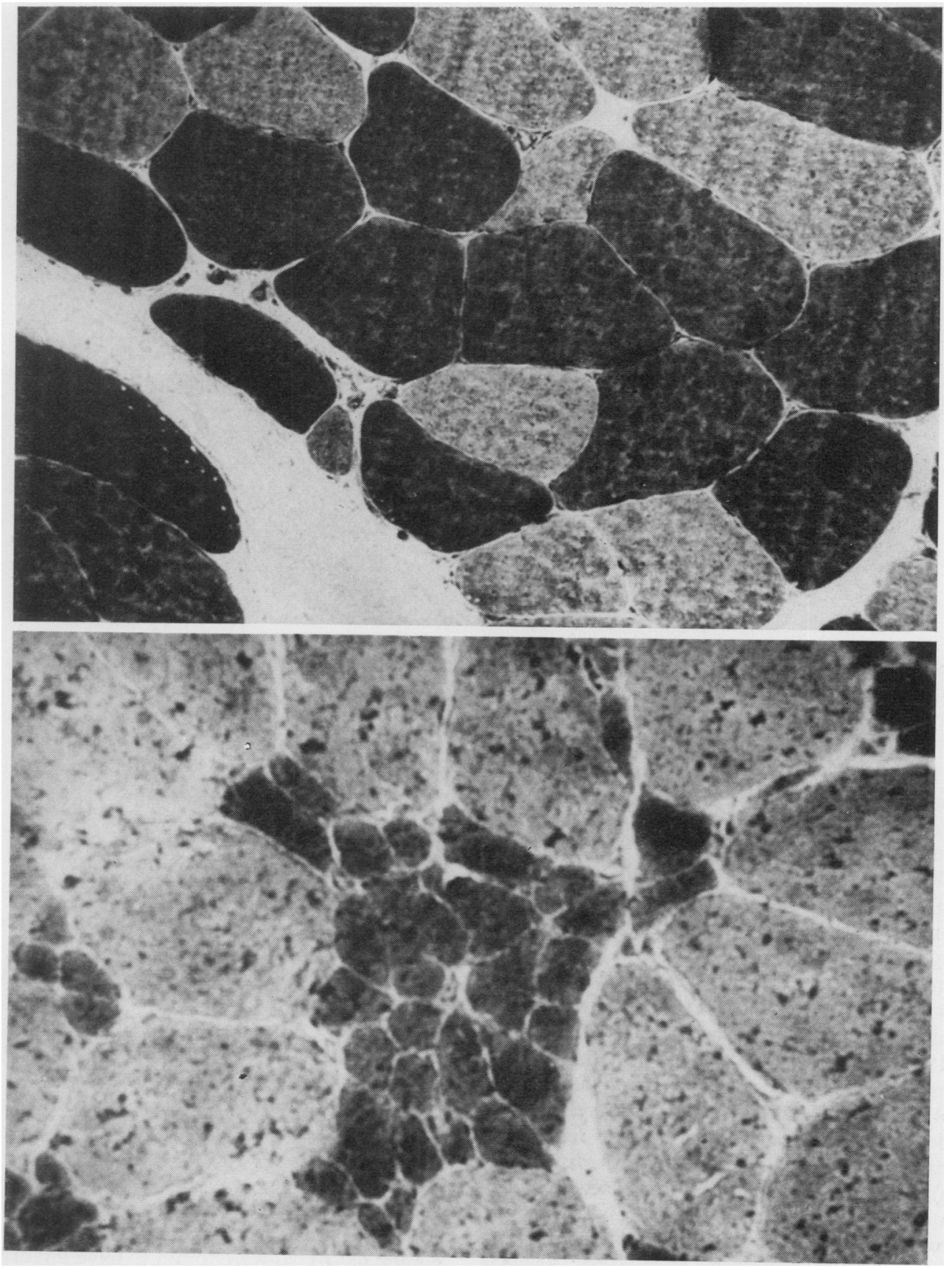

FIG. 3. Histochemical differentiation into fibre types. Quadriceps muscle. Above: normal muscle (ATPase; original $\times 400$ ). Below: type grouping (ATPase; original $\times 400$ ). 


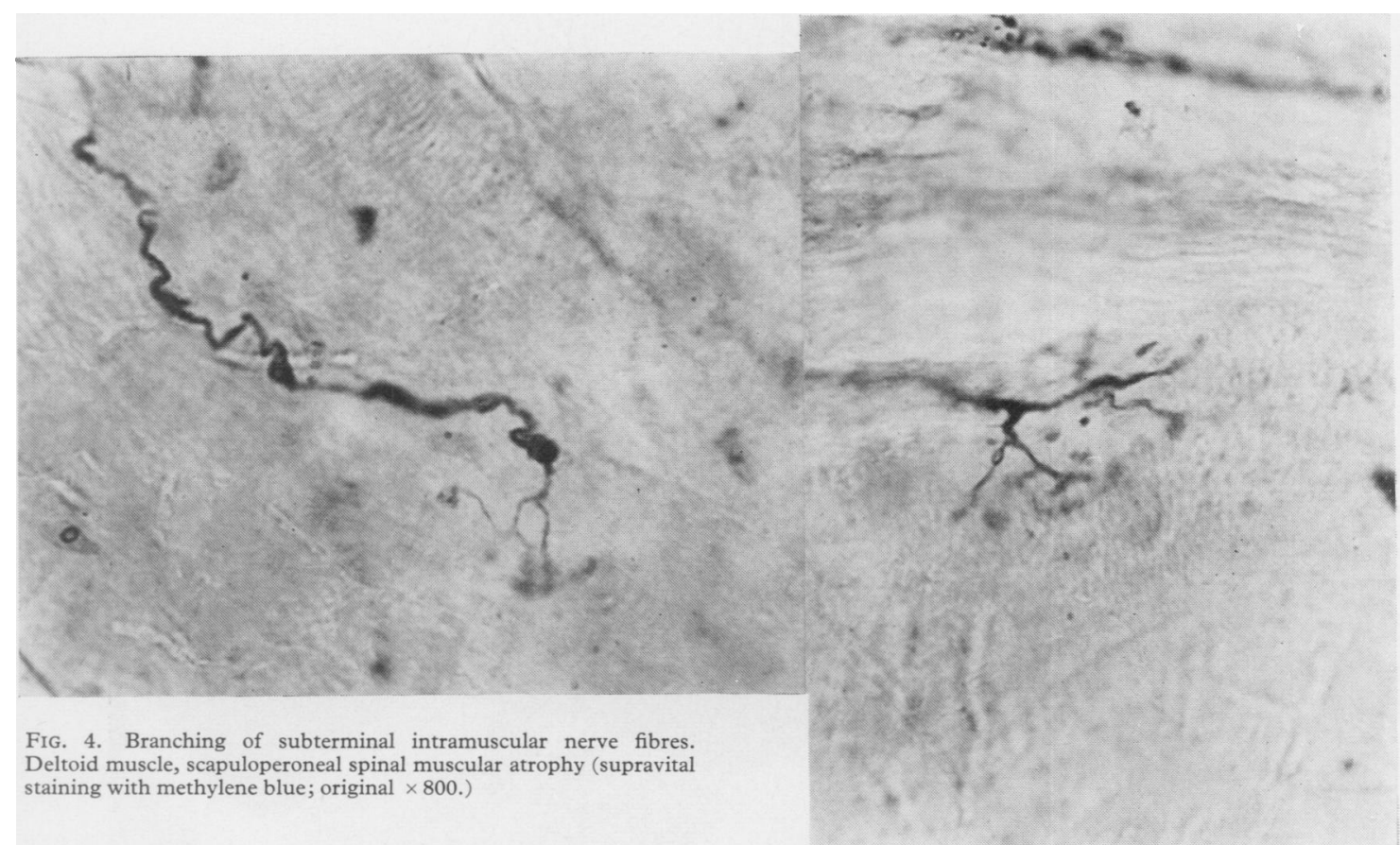

(Schott, Jacobi, and Wald, 1955; Manning and Cropp, 1958; Skyring and McKusick, 1961; Gilroy et al, 1963) and characteristically there are tall $\mathrm{R}$ waves in the right praecordial lead (Perloff et al, 1967; Emery, 1969; Emery and Spikesman, 1970). Though in other forms of dystrophy there are no specific abnormalities, the ECG is frequently abnormal (Lowenstein, Arbeit, and Rubin, 1962; Perloff, de Leon, and O'Doherty, 1966). In spinal muscular atrophy, however, apart from a fine tremor often most marked in the limb leads, the ECG is usually normal (Emery, 1972).

Some investigators have reported increased amounts of amino acids in urine and serum in some patients with spinal muscular atrophy (Almog and Tal, 1968; Gorecka, 1969). However this and the increased levels of creatine in urine and serum (Namba et al, 1970), probably merely reflect muscle wasting since they are most marked in patients with the severe infantile (Werdnig-Hoffmann) form and are also found in the severer forms of muscular dystrophy. Reported changes in the electrophoretic patterns of serum proteins in spinal muscular atrophy (Ionasescu et al, 1965; Askanas, 1967) are difficult to evaluate. Comparable abnormalities have also been described in muscular dystrophy by Askanas (1967) but A. Jacobs (personal communication) has been unable to confirm these findings. Other biochemical findings in this group of disorders have been reviewed by Namb et al (1970). No specific biochemical abnormality has yet been identified in any of this group of disorders and there is no detectable chromosome abnormality (Bonasegla and Montevecchi, 1970).

\section{'Amyotonia Congenita'}

Amyotonia congenita (myatonia congenita, Oppenheim's disease) is not a specific disease entity but refers to the syndrome of generalized muscular hypotonia, feebleness of voluntary movements, and depressed or absent tendon reflexes which is present at birth or is manifest during early infancy. Batten (1910) was the first to recognize that the syndrome could be myopathic in origin or result from a lesion in the anterior horn cell of the spinal cord (infantile spinal muscular atrophy). More recent studies have made it clear that the syndrome may in fact result from many causes (Brandt, 1950a and b; Walton, 1956 and 1957). In a follow-up study of 109 cases initially diagnosed as 'amyotonia congenita' $67(61 \%)$ were found to have infantile spinal muscular atrophy, $22(20 \%)$ had a myopathy, and the remainder had a variety of disorders including cerebral palsy, mental defect, and scurvy, etc (Walton, 1956). The congenital myopathies are 
themselves a heterogeneous group of disorders (Emery and Walton, 1967). For these reasons the term amyotonia congenita (or myatonia congenita or Oppenheim's disease) has no diagnostic significance.

\section{Classification}

In 1968, the Research Group on Neuromuscular Diseases (formerly the World Commission on Neuromuscular Diseases), with the direction of Professor J. N. Walton, subdivided the geneticallydetermined 'infantile and juvenile spinal muscular atrophies' into Werdnig-Hoffmann disease, arthrogryposis multiplex due to anterior horn cell disease, Kugelberg-Welander disease, and scapuloperoneal

\section{TABLE I}

CLINICOGENETIC CLASSIFICATION OF THE SPINAL MUSCULAR ATROPHIES

A. Proximal spinal muscular atrophy

I. Infantile (severe)

Autosomal recessive

II. Intermediate

? Autosomal recessive

III. Juvenile (relatively benign)

1. Autosomal recessive (and 'Ryukyuan' spinal muscular atrophy)

IV. Adult

2. Autosomal dominant

1. Autosomal recessive

2. Autosomal dominant

3. X-linked recessive

B. Distal spinal muscular atrophy

I. No sensory loss

1. Autosomal recessive

2. Autosomal dominant

II. With sensory loss

1. Autosomal recessive

2. Autosomal dominant

3. $\mathrm{X}$-linked recessive

4. X-linked dominant

C. Fuvenile progressive bulbar palsy

? Autosomal recessive

D. Scapuloperoneal spinal muscular atrophy

1. Autosomal dominant

2. ? Autosomal recessive

E. Facioscapulohumeral spinal muscular atrophy Autosomal dominant spinal muscular atrophy. Subsequent developments and experience suggest that further subdivision is justified.

An outline of the proposed classification of the spinal muscular atrophies based on clinical and genetic differences is given in Table I. However, until the primary biochemical $\operatorname{defect}(\mathrm{s})$ underlying spinal muscular atrophy is identified such a classification must remain tentative. Nevertheless since spinal muscular atrophy is clearly more than one genetic entity (Becker, 1966; McKusick, 1968; Furukawa et al, 1969; Zellweger et al, 1969b) a classification which is based on both genetic and clinical differences is valid and the best that is possible with our present knowledge.

\section{Infantile Spinal Muscular Atrophy (Werdnig-Hoffmann Disease)}

Werdnig (1891 and 1894) and Hoffmann (1893, $1900 \mathrm{a}$ and $\mathrm{b}$ ) were the first to describe a syndrome of progressive muscle weakness beginning in the first year of life and terminating in death in early childhood, usually before the age of 4. Both Werdnig and Hoffmann had observed extensive degenerative changes in the motor nuclei of the spinal cord in their patients and therefore this disorder was a muscular atrophy and not a dystrophy (Fig. 5). The clinical features of infantile spinal muscular atrophy or Werdnig-Hoffmann disease have since been described in detail by several investigators (Hanhart, 1945; Brandt, 1950a and b; Thieffry, Arthuis, and Bargeton, 1955; Fukuyama, 1958; Byers and Banker, 1961; Gamstorp, 1967).

The largest reported series is that of Brandt $(1950 \mathrm{a}$ and b). Of 106 children with infantile spinal muscular atrophy where there was adequate information, the onset was in the first year of life in $101(95 \%)$ while in 3 it commenced in the second year of life and in 1 at about 2 years of age. In 94 cases with adequate information, $76(81 \%)$ had died by age 4 . Some cases survived into adolescence but these may represent a different disorder (see below).

Concordance for infantile spinal muscular atrophy has been reported in identical twins (see Brandt, 1950a; Marquardt, MacLowry, and Perry, 1962; Zellweger et al, 1969b) and in Brandt's study (Brandt, 1950a) consanguinity was about 8 times greater among the parents of affected children than among controls. Family studies have shown that the condition is inherited as an autosomal recessive trait. Apparent exceptions in published cases can sometimes be ascribed to faulty diagnosis in affected 


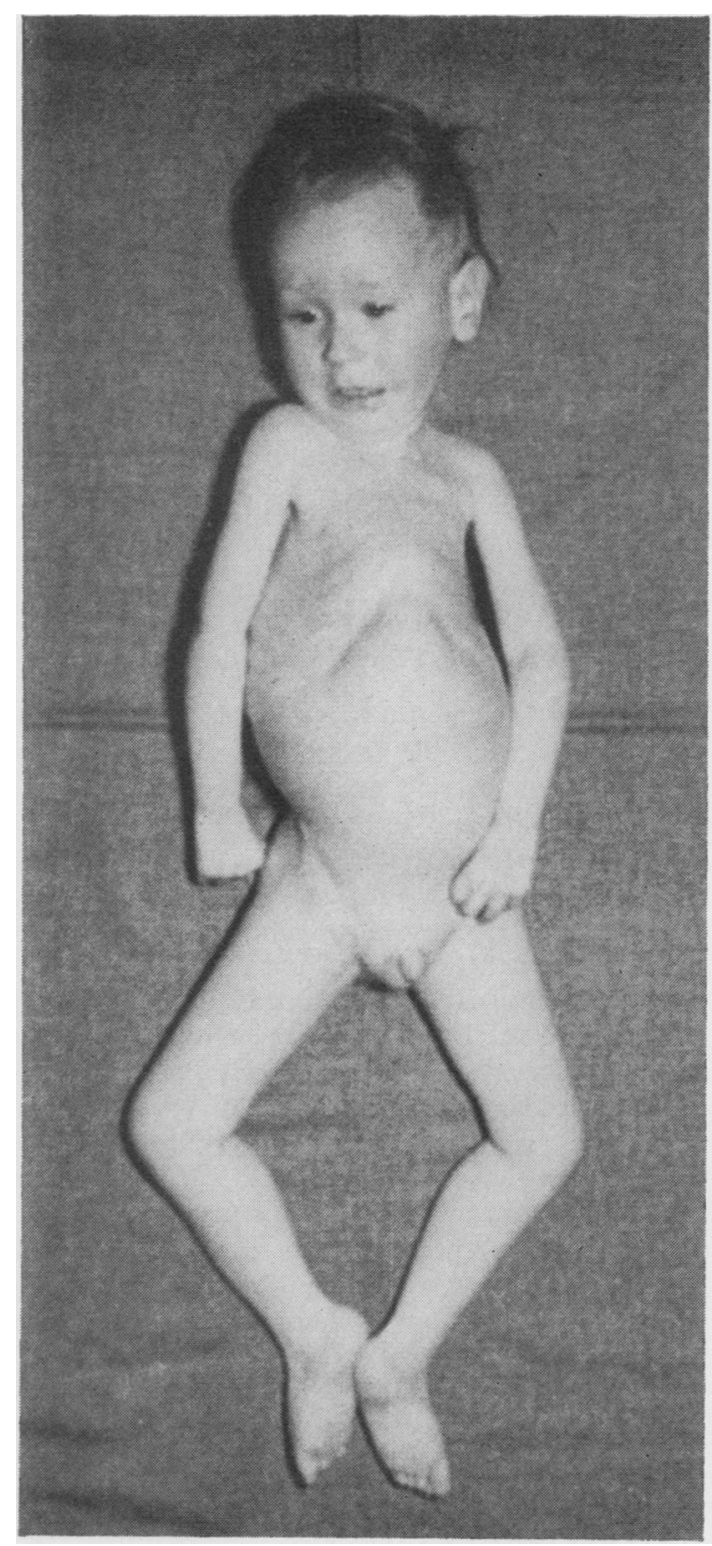

FIG. 5. Infantile spinal muscular atrophy (Werdnig-Hoffmann disease) in a $2 \frac{1}{2}$-year-old boy.

relatives (eg, Brandt, 1950a [families 1 and 16]) or to quasi-dominance due to inbreeding (eg, Brandt, 1950a [family 6]).

An association of arthrogryposis multiplex congenita and infantile spinal muscular atrophy in sibs has been reported (Frischknecht, Bianchi, and Pilleri, 1960; Bargeton et al, 1961) which may represent a separate disease entity. Of course the longer an affected individual survives the more likely it is that secondary contractures will develop.

\section{Juvenile Spinal Muscular Atrophy} (Wohlfart-Kugelberg-Welander Disease)

Wohlfart et al (1955) and Kugelberg and Welan$\operatorname{der}(1956)$ were the first to delineate a form of spinal muscular atrophy with proximal muscle weakness, more benign than infantile spinal muscular atrophy, with onset usually after the age of 2 and with survival often into adulthood. The clinical presentation in many ways resembles muscular dystrophy but differs in that fasciculations are often present and the EMG and muscle biopsy findings are typical of neurogenic atrophy and not dystrophy. Clinical features of this juvenile form (WohlfartKugelberg-Welander disease), have been reviewed by Namba et al (1970). Some investigators have reported that males are more severely affected than their female sibs (Dubowitz, 1964; Furukawa et al, 1968) but others have not been convinced of this (Kugelberg and Welander, 1956; Gardner-Medwin et al, 1967). The condition may be associated with arthrogryposis (Amick, Johnson, and Smith, 1967 [cases 7, 8, and 9]; Zellweger et al, 1969b [cases 13 and 15]).

Whether the infantile and autosomal recessive juvenile forms of spinal muscular atrophy can be separated on clinical grounds has been a matter of dispute. Some believe the distinction is artificial since it has been claimed that in a given sibship all gradations of severity can sometimes be seen (Byers and Banker, 1961; Dubowitz, 1964; Dunne and Chutorian, 1966; Rowland et al, 1967; Gardner-Medwin et al, 1967; Kessler, 1968; Meadows et al, 1969a; Munsat et al, 1969). But much of the confusion arises because of overlap in the age of onset. If other features are also taken into account, such as the course of the disease and age at death, then it would seem possible that these two disorders can be separated. Features which might be used to distinguish not only these two types of spinal muscular atrophy but also a possible intermediate type are summarized in Table II. Ages of onset and at death are approximate as the exact limits for each type have not yet been defined. It is possibly the failure to recognize the existence of an intermediate type which has made it difficult for investigators to separate these types of spinal muscular atrophy particularly when age at onset was used as the sole criterion (Fried and Emery, 1971).

The frequency of spontaneous activity on electromyography (Buchthal and Olsen, 1970) and the degree of collateral reinnervation (HausmanowaPetrusewicz et al, 1968) have also been found to 
TABLE II

INFANTILE (I), INTERMEDIATE (II), and JUVENILE (III) AUTOSOMAL RECESSIVE FORMS OF PROXIMAL SPINAL MUSCULAR ATROPHY

\begin{tabular}{|c|c|c|c|c|c|c|}
\hline \multirow{2}{*}{\multicolumn{2}{|c|}{ Type }} & \multicolumn{2}{|c|}{ Age } & \multirow{2}{*}{$\begin{array}{l}\text { Ability to } \\
\text { Sit } \\
\text { without } \\
\text { Support* }\end{array}$} & \multirow{2}{*}{$\begin{array}{c}\text { Fasciculations } \\
\text { of } \\
\text { Skeletal Muscles }\end{array}$} & \multirow{2}{*}{$\begin{array}{l}\text { Serum Creative } \\
\text { Kinase Levels }\end{array}$} \\
\hline & & Onset & Survival & & & \\
\hline III. & $\begin{array}{l}\text { Infantile } \\
\text { Intermediate } \\
\text { Juvenile }\end{array}$ & $\begin{array}{c}<12 \mathrm{mth} \\
3-18 \mathrm{mth} \\
>2 \mathrm{yr}\end{array}$ & $\begin{array}{c}<4 \mathrm{yr} \\
\quad>4 \mathrm{yr} \\
\text { Adulthood }\end{array}$ & $\begin{array}{l}\text { Never } \\
\text { Usually } \\
\text { Always }\end{array}$ & $\begin{array}{l}+1- \\
+1- \\
++\end{array}$ & $\begin{array}{l}\text { Normal } \\
\text { Usually normal } \\
\text { Often raised }\end{array}$ \\
\hline
\end{tabular}

* At some time during the course of the illness.

differ in the infantile and juvenile forms. The infantile, intermediate, and juvenile forms of proximal spinal muscular atrophy have been referred to as types I, II, and III respectively.

Autosomal Recessive Juvenile Spinal Muscular Atrophy. Juvenile spinal muscular atrophy has been described in identical twins (HausmanowaPetrusewicz et al, 1962; Zellweger et al, 1969b), and including those first described by Wohlfart et al (1955) and Kugelberg and Welander (1956) there have been many reports of families with multiple affected sibs suggesting autosomal recessive inheritance (Byers and Banker, 1961; Levy and Wittig, 1962; Castaigne et al, 1963; Dubowitz, 1964; Garvie and Woolf, 1966a; Radu et al, 1966; Gamstorp, 1967; Gardner-Medwin et al, 1967; Rowland et al, 1967; Peters et al, 1968; Meadows et al, 1969a; Hausmanowa-Petrusewicz, 1970). Consanguinity among the parents of affected individuals has also been noted (Hanhart, 1962; Spira, 1963; Radu et al, 1966; Almog and Tal, 1968). It has been reported that some healthy heterozygotes appear to have hyperaminoaciduria (Almog and Tal, 1968) or may be detected by electromyography (Spira, 1967). These findings await confirmation.

A possible variant of the juvenile type has been described in an inbred community in the Ryukyuan islands off Japan (Kondo, Tsubaki, and Sakamoto, 1970). This is characterized by the onset in infancy or early childhood of slowly progressive proximal muscle weakness most marked in the lower extremities and with pes cavus and scoliosis in some affected individuals. Muscle fasciculations were observed in several individuals, the serum level of creatine kinase was moderately elevated and there was no spontaneous activity in the electromyograph. The authors regarded this as a unique disorder and different from the usual form of juvenile spinal muscular atrophy.

Spiro, Fogelson, and Goldberg (1967) have described a family in which 3 brothers had a juvenile form of proximal spinal muscular atrophy associated with microcephaly and mental subnormality which may also represent a distinct genetic disorder.

Autosomal Dominant Juvenile Spinal Muscular Atrophy. Excluding families with quasidominance due to inbreeding (eg, the family of Almog and Tal [1968]) a number of families have been described where juvenile spinal muscular atrophy was inherited as an autosomal dominant trait with complete penetrance (Magee and de Jong, 1960; Armstrong, Fogelson, and Silberberg, 1966; Garvie and Woolf, 1966a; and Gamstorp, 1967). In some families where the disorder was clearly inherited as an autosomal dominant trait, penetrance was incomplete (Wohlfart et al, 1955 [family 2]; Kugelberg and Welander, 1956 [family 2]; Becker, 1964; Amick et al, 1966; Radu et al, 1966; Tsukagoshi et al, 1966).

The onset of the autosomal dominant form of juvenile spinal muscular atrophy is usually in early childhood but may be delayed until adolescence or even later (Kugelberg and Welander, 1956 [case 3]; Becker, 1964; Tsukagoshi et al, 1966 [case III-2]). Affected individuals develop proximal muscle weakness which is relatively slowly progressive and several patients have been reported in middle age yet still ambulatory. The condition seems to be milder than the autosomal recessive form which, from reported familial cases of juvenile spinal muscular atrophy appears to be at least 10 times commoner than the autosomal dominant form.

Case Report. We have studied a mother and daughter (HG 243) with this form of spinal muscular atrophy. The mother was born 4 June 1942 with talipes equinovarus which responded to conservative therapy. She has been aware of weakness in her legs from childhood which does not seem to have progressed over the years. She cannot get up from a crouching position and has difficulty climbing stairs. On examination there was weakness of her pelvic girdle musculature, her cranial nerves were intact and no fasciculations were observed. The serum level of creatine kinase was $48.0 \mu$ moles/ $\mathrm{min} / 1$ (normal less than 50 ). The diagnosis of spinal 
muscular atrophy was confirmed by EMG examination and muscle biopsy. Her daughter (born 6 January 1966) was noticed to walk with a waddle from about 2 years of age. At present she has difficulty climbing stairs and cannot run as well as other children. The weakness does not appear to have progressed. The serum level of creatine kinase was $42.0 \mu \mathrm{moles} / \mathrm{min} / 1$. No one else in the family has been similarly affected and there is no consanguinity.

\section{'Intermediate' Type of Spinal Muscular Atrophy}

Several authorities have speculated upon the possibility of a form of spinal muscular atrophy intermediate in severity between the infantile and juvenile forms (Gamstorp, 1967; Verger et al, 1969; Hausmanowa-Petrusewicz, 1970). In fact some of the earliest well documented cases of spinal muscular atrophy could be considered as belonging to this type (Thomson and Bruce, 1893; Hoffmann, 1900a). Some features which might be used to distinguish this type (intermediate or type II proximal spinal muscular atrophy) are summarized in Table II. There is some overlap in age of onset with infantile spinal muscular atrophy but in the intermediate type it appears that most patients survive beyond 4 years and usually into adolescence or later (Fried and Emery, 1971). The diagnosis of intermediate or type II spinal muscular atrophy, if it is to be entertained at all, should therefore rest on several criteria. It seems possible that this type of spinal muscular atrophy is inherited as an autosomal recessive trait (Fried and Emery, 1971). However, to account for the possibility of mild and severe forms of juvenile spinal muscular atrophy, Becker (1964) has suggested that besides the normal gene (a), being present in about $90 \%$ of the population, there are 3 mutant alleles $\left(a^{+}, a^{\prime}\right.$, and $\left.a^{\prime \prime}\right)$ such that $\mathrm{a}^{+} \mathrm{a}$ produces a normal phenotype, $\mathrm{a}^{+} \mathrm{a}^{\prime}$ produces a milder disease with later onset, and $a^{+} a^{\prime \prime}$ produces a severer disease with earlier onset ('intermediate' type). Such a hypothesis might also explain some of the cases of apparent nonpenetrance where the only other affected individual in a family is a second- or third-degree relative of the proband (Zellweger, Schneider, and Schuldt, 1969a).

\section{Adult Spinal Muscular Atrophy}

This group of disorders present as progressive muscle weakness with onset usually after the third decade of life. Since we are only concerned with disorders associated with degeneration of the anterior horn cells and not the pyramidal tracts, motor neurone disease (and its variants) and the various forms of amyotrophy are excluded; the genetics of these forms have been discussed in detail elsewhere (Pratt, 1967; Kloepfer and Emery, 1969).

The main clinical feature of adult spinal muscular atrophy is slowly progressive proximal limb weakness, and is therefore easily confused with limb girdle muscular dystrophy or chronic polymyositis but the distinction can be made on electromyographic examination or muscle histology. The bulbar nuclei may also become involved and the serum creatine kinase level may be moderately elevated. The prognosis is usually good.

Cases have been described which were sporadic (Hurwitz, Lapresle, and Garcin, 1961; Smith and Patel, 1965; Gross, 1966; Cazzato, 1969) or inherited as autosomal recessive traits (Funk, 1962; Tsukagoshi et al, 1965 [cases 1, 2, and 3 and possibly 5]; Mapelli and Ramelli, 1970), autosomal dominant traits (Tsukagoshi et al, 1965 [case 4], Peters et al, 1968 [family 13] and possibly the large family described by Finkel [1962]), or as X-linked recessive traits (Kennedy, Alter, and Foreman, 1966; Kennedy, Alter, and Sung, 1968; Shoji et al, 1970). An X-linked form of adult spinal muscular atrophy with a slightly earlier age of onset has also been described (Tsukagoshi, Shoji, and Furukawa 1970). The 3 affected brothers reported b. Magee (1960) might also belong to this categor though the muscle weakness appeared to be slightly more marked distally. The association of adult spinal muscular atrophy with type II hyperlipoproteinaemia reported by Quarfordt et al (1970) was probably coincidental.

At present there appears to be no clinical means of distinguishing between patients affected with the autosomal dominant, autosomal recessive, or $\mathrm{X}$ linked recessive forms of adult spinal muscular atrophy.

\section{Distal Spinal Muscular Atrophy}

Without Sensory Loss. A number of cases have been described of a relatively benign form of spinal muscular atrophy with onset usually in early childhood in which muscle weakness is predominantly distal and there is no sensory loss. Affected individuals often survive at least to middle age. Charcot-Marie-Tooth disease is somewhat similar to this disorder, but as Meadows et al (1969b) have pointed out, in the former condition the legs are typically more severely affected than the arms, peripheral sensory abnormalities can usually be detected if carefully sought for and motor nerve conduction velocities are usually reduced, features not 
found in distal spinal muscular atrophy. The group of patients described by Dyck and Lambert (1968b) as having 'progressive spinal muscular atrophy of Charcot-Marie-Tooth type' might be logically included under the heading of distal spinal muscular atrophy.

In some families this disorder has been sporadic (Gardner-Medwin et al, 1967 [case 17]; Ricker, Mertens, and Schimrigk, 1968 [case 3]) but in others, sibs have been similarly affected (MartinSneessens, 1962; Meadows and Marsden, 1969), suggesting autosomal recessive inheritance. However Lugaresi, Gambetti, and Rossi (1966) have described a father and son with what could be considered distal spinal muscular atrophy. A family with an autosomal dominant form of distal spinal muscular atrophy with onset in early adult life has been described by Nelson and Amick (1966).

With Sensory Loss. This group of disorders is often referred to as peroneal muscular atrophy or Charcot-Marie-Tooth disease. Weakness usually starts in the feet and legs and later affects the hands. Not only are the anterior horn cells of the spinal cord involved but also the peripheral nerves with some posterior column degeneration resulting in sensory loss over the areas of muscle weakness and there is slowing of nerve conduction, features not found in true spinal muscular atrophy. This group of disorders is included for the sake of completeness. Their clinical features have been discussed in detail by Becker (1966), Pratt (1967), and Dyck and Lambert (1968a and $b$ ). The mode of inheritance may be as an autosomal recessive or autosomal dominant trait (Dyck and Lambert, 1968a and b), as an Xlinked recessive trait (see Pratt, 1967), or rarely as an X-linked dominant trait (Woratz, 1964). In general the recessive disorder is more severe than the dominant and the $\mathrm{X}$-linked forms are intermediate (Allen, 1939).

\section{Juvenile Progressive Bulbar Palsy (Fazio-Londe Disease)}

Sometimes referred to as Fazio-Londe disease, this disorder is characterized by progressive cranial nerve paralyses (ophthalmoplegia, facial paralysis, laryngeal palsy, etc) dating from early childhood. The disorder has been reviewed by Gomez, Clermont, and Bernstein (1962). The mode of inheritance has usually been consistent with that of an autosomal recessive trait though the mother of the patient originally described by Fazio was also affected.

Chronic progressive bulbar palsy with onset in childhood or adolescence and associated with bilateral perceptive deafness (Van Laere's syndrome) may be sporadic (Trillet et al, 1970) but can apparently be inherited as an autosomal recessive trait (Van Laere, 1966).

In juvenile spinal muscular atrophy there is usually only minimal clinical involvement of the cranial nerves but progressive ophthalmoplegia and dysphagia were the main features in a 15-year-old boy with this disorder described by Aberfeld and Namba (1969). However, involvement of the cranial nerves was a late manifestation in the course of the disease whereas in juvenile progressive bulbar palsy it is the main feature from the onset.

\section{Scapuloperoneal Spinal Muscular Atrophy}

The remaining two types of spinal muscular atrophy, namely scapuloperoneal and facioscapulohumeral, are classified separately because of the distinctive patterns of muscle weakness in these two disorders both of which have counterparts among the muscular dystrophies.

In scaculoperoneal spinal muscular atrophy weakness is mainly localized to the pectoral girdle musculature and the peroneal muscles and is very slowly progressive (Fig. 6). There may or may not be any facial weakness, and there is no sensory loss. The onset is usually in the second or third decade but at least in some of the sporadic cases which have been described onset has been in childhood (Emery, Fenichel, and Eng, 1968; Munsat, 1968; Zellweger and McCormick, 1968; Schuchmann, 1970).

When inherited it usually behaves as an autosomal dominant trait (Kaeser, 1965; Ricker et al, 1968 [case 1]; Tsukagoshi et al, 1969). However, we have had an opportunity to study a family where the disorder appears to be inherited as an autosomal recessive trait.

Case Report. The propositus (HG 388) now aged 19 , was perfectly well until 6 years ago when he first became aware of weakness in his shoulders and arms. Four years ago weakness developed in his peroneal muscles and more recently there has been some weakness in the extensors of his right wrist. He also has some slight facial weakness. The serum creatine kinase level was moderately raised $(134 \mu \mathrm{moles} / \mathrm{min} / \mathrm{l})$. The diagnosis of spinal muscular atrophy was confirmed by EMG examination, muscle histology, and motor endplate biopsy. He has 3 sibs who are healthy and a sister (aged 30) who is similarly affected. The parents are healthy and unrelated. There is no family history of anyone else being similarly affected.

\section{Facioscapulohumeral Spinal Muscular Atrophy}

In this disorder weakness is mainly confined to the 


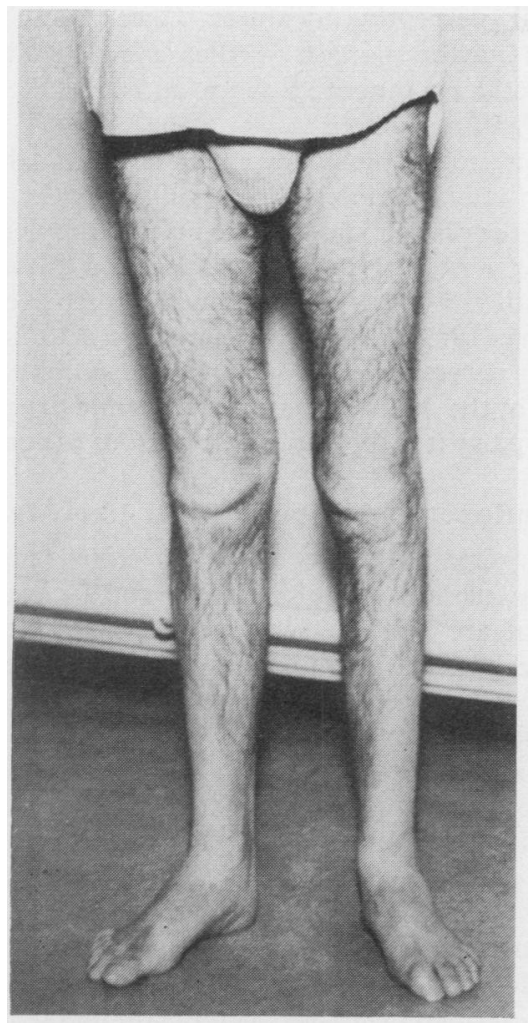

Fig. 6. Scapuloperoneal spinal muscular atrophy. Note wasting of the lower legs.

face and pectoral girdle musculature. The onset is in early adult life and is thereafter slowly progressive. Sporadic cases have been described (Furukawa et al, 1969) but the disorder can be inherited as an autosomal dominant trait (Fenichel, Emery, and Hunt, 1967). Clinically it resembles facioscapulohumeral muscular dystrophy from which it can be differentiated by electromyography and muscle histology.

\section{Conclusions}

The proposed classification of the spinal muscular atrophies based on the distribution of muscle weakness and on genetic differences must be tentative until the basic biochemical defect(s) underlying this group of disorders has been identified. Nevertheless even without this knowledge we might hope that it will soon be possible on clinical, or other grounds, to differentiate between the various genetic forms of spinal muscular atrophy which would be of considerable value in genetic counselling, prognosis, and for linkage and other genetic studies.
Original work reported in this review was supported by the MRC and the Muscular Dystrophy Group of Great Britain.

\section{REFERENCES}

Aberfeld, D. C. and Namba, T. (1969). Progressive ophthalmoplegia in Kugelberg-Welander disease. Archives of Neurology, 20, 253-256.

Allan, W. (1939). Relation of hereditary pattern to clinical severity as illustrated by peroneal atrophy. Archives of Internal Medicine, 63, 1123-1131.

Almog, C. and Tal, E. (1968). A family with Kugelberg-Welander syndrome. Confinia Neurologica, 30, 313-324.

Amick, L. D., Smith, H. L., and Johnson, W. W. (1966). An unusual spectrum of progressive spinal muscular atrophy. Acta Neurologica, 42, 275-295.

Amick, L. D., Johnson, W. W., and Smith, H. L. (1967). Electromyographic and histopathologic correlations in arthtogryposis. Archives of Neurology, 16, 512-523.

Armstrong, R. M., Fogelson, M. H., and Silberberg, D. H. (1966). Familial proximal spinal muscular atrophy. Archives of Neurology, 14, 208-212.

Askanas, W. (1967). Immunoelectrophoretic investigations of blood serum proteins in muscular diseases. Fournal of Neurology, Neurosurgery and Psychiatry, 30, 43-46.

Bargeton, E., Nezelof, C., Guran, P., and Job, J. C. (1961). Étude anatomique d'un cas d'arthrogrypose multiple congénitale et familiale. Revue Neurologique, 104, 479-489.

Batten, F. E. (1910). Critical review: the myopathies or muscular dystrophies. Quarterly Fournal of Medicine, 3, 313-328.

Becker, P. E. (1964). Atrophia musculorum spinalis pseudomyopathica hereditäre neurogene proximale Amyotrophie von Kugelberg und Welander. Zeitschrift für menschliche Vererbungsund Konstitutionslehre, 37, 192-220.

Becker, P. E. (1966). Humangenetik. Thieme, Stuttgart.

Beckmann, R., Manz, F., and Moser, R. (1970). Gehäuftes 'sporadisches' Vorkommen spinaler progressiver Muskelatrophien im Kindesalter. Monatsschrift für Kinderheilkunde, 118, 41-44.

Bonasegla, F. and Montevecchi, M. T. (1970). Clinical and laboratory of the Wohlfart-Kugelberg-Welander syndrome. In Muscle Diseases, ed. by J. N. Walton, N. Canal, and G. Scarlato, pp. 546-550. Excerpta Medica International Congress Series No. 199, Amsterdam.

Brandt, S. (1950a). Werdnig-Hoffman's Infantile Progressive Muscular Atrophy. Munksgaard, Copenhagen.

Brandt, S. (1950b). Course and symptoms of progressive infantile muscular atrophy. Archives of Neurology and Psychiatry, 63, 218-228.

Brown, J. C. and Johns, R. J. (1970). Abnormal motor nerve excitability in amyotrophic lateral sclerosis. Fohns Hopkins Medical fournal, 127, 55-63.

Buchthal, F. and Olsen, P. Z. (1970). Electromyography and muscle biopsy in infantile spinal muscular atrophy. Brain, 93, 15-30.

Byers, R. K. and Banker, B. Q. (1961). Infantile muscular atrophy. Archives of Neurology, 5, 140-164.

Castaigne, P., Cambier, J., Plane, D. la, Escourolle, R., Boudouresques, J., and Paillerets, F. de (1963). Amyotrophie neurogène familiale pseudo-myopathique de la seconde enfance. Revue Neurologique, 109, 13-20.

Cazzato, G. (1969). Le amiotrofie spinali progressive pseudomiopatiche dell' adulto. Acta Neurologica (Naples), 24, 341-370.

Coërs, C. and Woolf, A. L. (1959). The Innervation of Muscle-A Biopsy Study. Blackwell, Oxford.

Drachman, D. B., Murphy, S. R., Nigam, M. P., and Hills, J. R. (1967). 'Myopathic' changes in chronically denervated muscle. Archives of Neurology, 16, 14-24.

Dubowitz, V. (1964). Infantile muscular atrophy. A prospective study with particular reference to a slowly progressive variety. Brain, 87, 707-718.

Dubowitz, V. (1967). Pathology of experimentally re-innervated skeletal muscle. Fournal of Neurology, Neurosurgery and Psychiatry, 30, 99-110.

Dubowitz, V. and Roy, S. (1970). Central core disease of muscle: clinical, histochemical and electron microscopic studies of an affected mother and child. Brain, 93, 133-146. 
Duchen, L. W., Strich, S. J., and Falconer, D. S. (1968). An hereditary motor neurone disease with progressive denervation of muscle in the mouse: the mutant 'wobbler'. Fournal of Neurology, Neurosurgery and Psychiatry, 31, 535-542.

Dunne, P. B. and Chutorian, A. M. (1966). The relationship between infantile and juvenile spinal muscular atrophy. Neurology, 16, 306.

Dyck, P. J. and Lambert, E. H. (1968a). Lower motor and primary sensory neuron diseases with peroneal muscular atrophy. I. Neurologic, genetic and electrophysiologic findings in hereditary polyneuropathies. Archives of Neurology, 18, 603-618.

Dyck, P. J. and Lambert, E. H. (1968b). Lower motor and primary sensory neuron diseases with peroneal muscular atrophy. II. Neurologic, genetic and electrophysiologic findings in various neuronal degenerations. Archives of Neurology, 18, 619-625.

Emery, A. E. H. (1969). Abnormalities of the electrocardiogram in female carriers of Duchenne muscular dystrophy. British Medical fournal, 2, 418-420.

Emery, A. E. H. (1972). Abnormalities of the electrocardiogram in hereditary myopathies. Fournal of Medical Genetics, 9. (In press.)

Emery, A. E. H. and Spikesman, A. (1970). Evidence against the existence of a subclinical form of X-linked Duchenne muscular dystrophy. Fournal of the Neurological Science, 10, 523-533.

Emery, A. E. H. and Walton, J. N. (1967). The genetics of muscular dystrophy. In Progress in Medical Genetics, ed. by A. G. Steinberg and A. G. Bearn, vol. 5, pp. 116-145. Grune and Stratton, New York.

Emery, E. S., Fenichel, G. M., and Eng, G. (1968). A spinal muscular atrophy with scapuloperoneal distribution. Archives of Neurology, 18, 129-133.

Engel, W. K. (1961). Muscle target fibres, a newly recognised sign of denervation. Nature (London), 191, 389-390.

Engel, W. K. (1970). Selective and non-selective susceptibility of muscle fibre types. Archives of Neurology, 22, 97-117.

Fenichel, G. M., Emery, E. S., and Hunt, P. (1967). Neurogenic atrophy simulating facioscapulohumeral dystrophy. Archives of Neurology, 17, 257-260.

Finkel, N. (1962). A forma pseudomiopatica tardia da atrofia muscular progressiva heredo-familial. Arquivos de NeuroPsiquiatria, 20, 307-322.

Fried, K. and Emery, A. E. H. (1971). Spinal muscular atrophy, type II. Clinical Genetics, 2, 203-209.

Frischknecht, W., Bianchi, L., and Pilleri, G. (1960). Familiäre Arthrogryposis multiplex congenita Neuro-arthro-myodyplasia congenita. Helvetica Paediatrica Acta, 15, 259-279.

Fukuyama, Y. (1958). Infantile progressive muscular atrophy (Werdnig-Hoffmann) in relation to myatonia congenita (Oppenheim). Six cases including two autopsy cases. Paediatria Universitatis (Tokyo), 2, 39-44.

Funk, F. (1962). Zur familiären Form der progressiven spinalen Muskelatrophie. Fortschritte der Neurologie, Psychiatrie und ihrer Grenzgebiete, 30, 324-330.

Furukawa, T., Nakao, K., Sugita, H., and Tsukagoshi, H. (1968). Kugelberg-Welander disease, with particular reference to sexinfluenced manifestations. Archives of Neurology, 19, 156-162.

Furukawa, T., Tsukagoshi, H., Sugita, H., and Toyokura, Y. (1969). Neurogenic muscular atrophy simulating facioscapulohumeral muscular dystrophy. Fournal of the Neurological Sciences, 9, 389-397.

Gamstorp, I. (1967). Progressive spinal muscular atrophy with onset in infancy or early childhood. Acta Paediatrica, 56, 408423.

Gardner-Medwin, D., Hudgson, P., and Walton, J. N. (1967) Benign spinal muscular atrophy arising in childhood and adolescence. Fournal of the Neurological Sciences, 5, 121-158.

Gardner-Medwin, D. and Walton, J. N. (1969). A classification of the neuromuscular disorders and a note on the clinical examination of the voluntary muscles. In Disorders of Voluntary Muscle, ed. by J. N. Walton, pp. 411-453. Churchill. London.

Garvie, J. M. and Woolf, A. L. (1966a). Kugelberg-Welander syndrome (hereditary proximal spinal muscular atrophy). British Medical fournal, 1, 1458-1461.

Gomez, M. R., Clermont, V., and Bernstein, J. (1962). Progressive bulbar paralysis in childhood (Fazio-Londe's disease). Report of a case with pathologic evidence of nuclear atrophy. Archives of Neurology, 6, 317-323.
Gorecka, A. (1969). Aminoacyduria i aminoacydemia w chorobach miesni pochodzenia rdzeniowego. Neurologia Neurochirurgia (Polska), 3, 607-612.

Gross, M. (1966). Proximal spinal muscular atrophy. fournal of Neurology, Neurosurgery and Psychiatry, 29, 29-34.

Hanhart, E. (1945). Die infantile progressive spinale Muskelatrophie (Werdnig-Hoffmann) als einfach - rezessive, subletale Mutation auf Grund von 29 Fällen in 14 Sippen. Helvetica Paediatrica Acta, 1, 110-133.

Hanhart, E. (1962). Die Genealogie der 6 sicheren und 4 wahrscheinlichen Fälle von neurogener, proximaler Amyotrophie (Kugelberg-Welander) in einer Sippe aus dem Isolat I (Kanton Schwyz). Archiv der fulius Klaus-Stiftung für Vererbungsforschung, Sozialanthropologie, und Rassenhygiene, 37, 175-193.

Hausmanowa-Petrusewicz, I. (1970). Infantile and juvenile spinal muscular atrophy. In Muscle Diseases, ed. by J. N. Walton, N. Canal, and G. Scarlato, pp. 558-567. Excerpta Medica International Congress Series No. 199, Amsterdam.

Hausmanowa-Petrusewicz, I., Sobkowicz, H., Zielinska, S., and Dobosz, I. (1962). A propos d'atrophies musculaires juvéniles hérédo-familiales. Schweizer Archiv für Neurologie, Neurochirurgie und Psychiatrie, 90, 255-267.

Hausmanowa-Petrusewicz, I., Askana, W., Badurska, B., Emeryk, B., Fidziańska, A., Garbalińska, W., Hetnarska, L., Jędrzejowska, H., Kamieniecka, Z., Niebrót-Dobosz, I., Prot, J., and Sawicka, E. (1968). Infantile and juvenile spinal muscular atrophy. fournal of the Neurological Sciences, 6, 269-287.

Hetnarska, L., Prot, J., and Sawicka, E. (1968). Creatine phosphokinase activity in spinal muscular atrophy. Fournal of the Neurological Sciences, 6, 261-267.

Hoffmann, J. (1893). Ueber chronische spinale Muskelatrophie im Kindesalter auf familiärer Basis. Deutsche Zeitschrift für Nervenheilkunde, 3, 427-470.

Hoffmann, J. (1900a). Ueber die hereditäre progressive spinale Muskelatrophie im Kindesalter. Münchener Medizinische Wochenschrift, 47, 1649-1651.

Hoffmann, J. (1900b). Dritter Beitrag zur Lehre von der hereditärer progressiven spinalen Muskelatrophie im Kindesalter. Deutsche Zeitschrift für Nervenheilkunde, 18, 217-224.

Hogenhuis, L. A. H., Spaulding, S. W., and Engel, W. K. (1967). Neuronal RNA metabolism in infantile spinal muscular atrophy (Werdnig-Hoffmann's disease) studied by radioautography. A new technique in the investigation of neurological disease. fournal of Neuropathology and Experimental Neurology, 26, 335341.

Hurwitz, L., Lapresle, J., and Garcin, R. (1961). Atrophie musculaire neurogène de topographie proximale et symétrique simulant une myopathie: étude de deux observations. Revue Neurologique, 104, 97-107.

Ionasescu, V., Luca, N. Petrescu, A., and Calcaianu, G. (1965). Hereditary proximal spinal muscular atrophy. Biochemical investigations. Confinia Neurologica, 25, 79-86.

Kaeser, H. E. (1965). Scapuloperoneal muscular atrophy. Brain, $88,407-418$.

Kennedy, W. R., Alter, M., and Foreman, R. T. (1966). Hereditary proximal spinal muscular atrophy of late onset. Neurology, 16, 306-307.

Kennedy, W. R., Alter, M., and Sung, J. H. (1968). Progressive proximal spinal and bulbar muscular atrophy of late onset. A sex-linked recessive trait. Neurology, 18, 671-680.

Kessler, G. B. (1968). Non-progressive proximal and generalized spinal muscular atrophy in siblings. Bulletin of the Los Angeles Neurological Societies, 33, 21-25.

Kloepfer, H. W. and Emery, A. E. H. (1969). Genetic aspects of neuromuscular disease. In Disorders of Voluntary Muscle, ed. by J. N. Walton, pp. 683-712. Churchill, London.

Kohn, R. (1968). Postmortem findings in a case of Wohlfart-Kugelberg-Welander disease. Confinia Neurologica, 30, 253-260.

Kondo, K., Tsubaki, T., and Sakamoto, F. (1970). The Ryukyuan muscular atrophy. An obscure heritable neuromuscular disease found in the islands of Southern Japan. Fournal of the Neurological Sciences, 11, 359-382.

Kugelberg, E. and Welander, L. (1956). Heredofamilial juvenile muscular atrophy simulating muscular dystrophy. Archives of Neurology and Psychiatry, 75, 500-509.

Lambert, E. H. (1963). Electromyography and electric stimulation of peripheral nerves and muscles. In Clinical Examinations in 
Neurology, 2nd ed., pp. 311-341. Saunders, London and Philadelphia.

Levy, J. A. and Wittig, E. O. (1962). Atrofia muscular proximal familiar. Arquivos de Neuro-Psiquiatria, 20, 233-237.

Lowenstein, A. S., Arbeit, S. R., and Rubin, I. L. (1962). Cardiac involvement in progressive muscular dystrophy. An electrocardiographic and ballistocardiographic study. American fournal of Cardiology, 9, 528-533.

Lugaresi, E., Gambetti, P., and Rossi, P. G. (1966). Chronic Neurogenic muscle atrophies of infancy. Their nosological relationship with Werdnig-Hoffmann's disease. Fournal of the Neurological Sciences, 3, 399-409.

McKusick, V. A. (1968). Mendelian Inheritance in Man, 2nd ed. Johns Hopkins, Baltimore.

Magee, K. R. (1960). Familial progressive bulbarspinal muscular atrophy. Neurology, 10, 295-305.

Magee, K. R. and Jong, R. N. de (1960). Neurogenic muscular atrophy simulating muscular dystrophy. Archives of Neurology, 2, 677-682.

Manning, G. W. and Cropp, G. J. (1958). The electrocardiogram in progressive muscular dystrophy. British Heart fournal, 20, 416-420.

Mapelli, G. and Ramelli, E. (1970). Familial progressive spinal amyotrophy with limb root distribution and onset in adult life (neurogenic pseudomyopathy of Wohlfart-Kugelberg-Welander). In Muscle Diseases, ed. by J. N. Walton, N. Canal and G. Scarlato, pp. 551-554. Excerpta Medica International Congress Series No. 199, Amsterdam.

Marburg, O. (1912). Zur Klinik und Pathologie der Myatonia congenita (Appenheim). Arbeiten aus der Neurologischen Institut an der Wiener Universität, 19, 133-154. Quoted by Brandt (1950a).

Marquardt, J. E., MacLowry, J., and Perry, R. E. (1962). Infantile progressive spinal muscular atrophy in identical Negro twins. New England fournal of Medicine, 267, 386-388.

Martin-Sneessens, L. (1962). Formes à évolution très prolingée de l'amyotrophie spinale de Werdnig-Hoffmann. Fournal de Génétique Humaine, 11, 251-269.

Meadows, J. C. and Marsden, C. D. (1969). A distal form of chronic spinal muscular atrophy. Neurology, 19, 53-58.

Meadows, J. C., Marsden, C. D., and Harriman, D. G. F. (1969a), Chronic spinal muscular atrophy in adults. Part I. The Kugelberg-Welander syndrome. Fournal of the Neurological Sciences, 9, 527-550.

Meadows, J. C., Marsden, C. D., and Harriman, D. G. F. (1969b). Chronic spinal muscular atrophy in adults. Part 2. Other forms. fournal of the Neurological Sciences, 9, 551-566.

Mumenthaler, M. (1970). Myopathy in neuropathy In Muscle Diseases, ed. by J. N. Walton, N. Canal, and G. Scarlato, pp. 585598. Excerpta Medica International Congress Series No. 199, Amsterdam.

Munsat, T. L. (1968). Quoted by Zellweger and McCormick (1968).

Munsat, T. L., Woods, R., Fowler, W., and Pearson, C. M. (1969). Neurogenic muscular atrophy of infancy with prolonged survival. The variable course of Werdnig-Hoffmann disease. Brain, 92, 9-24.

Namba, L., Aberfeld, D. C., and Grob, D. (1970). Chronic proximal spinal muscular atrophy. Fournal of the Neurological Sciences, 11, 401-423.

Nelson, J. W. and Amick, L. D. (1966). Heredofamilial progressive spinal muscular atrophy: a clinical and electromyographic study of a kinship. Neurology, 16, 306.

Pearce, J. and Harriman, D. G. F. (1966). Chronic spinal muscular atrophy. Fournal of Neurology Neurosurgery and Psychiatry, 29, 509-520.

Perloff, J. K., Leon, A. C. de, and O'Doherty, D. (1966). The cardiomyopathy of progressive muscular dystrophy. Circulation, 33, 625-648.

Perloff, J. K., Roberts, W. C., Leon, A. C. de, and O'Doherty, D. (1967). The distinctive electrocardiogram of Duchenne's progressive muscular dystrophy. American fournal of Medicine, 42, 179-188.

Peters, H. A., Opitz, J. M., Goto, I., and Reese, H. H. (1968). The benign proximal spinal progressive muscular atrophies. A clinical and genetical study. Acta Neurologica, 44, 542-560.

Pratt, R. T. C. (1967). The Genetics of Neurological Disorders. Oxford University Press, London.
Quarfordt, S. H., Vivo, D. C. de, Engel, W. K., Levy, R. I., and Fredrickson, D. S. (1970). Familial adult-onset proximal spinal muscular atrophy. Archives of Neurology, 22, 541-549.

Radu, H., Seceleanu, A., Migea, S., Torok, Z., Bordeianu, L., and Seceleanu, S. (1966). La pseudomyopathie neurogène de Kugelberg-Welander. Acta Neurologica Psychiatrica, 66, 409427.

Research Group on Neuromuscular Diseases (1968). Classification of the neuromuscular disorders (Appendix A). Fournal of the Neurological Sciences, 6, 165-177.

Ricker, K., Mertens, H. G., and Schimrigk, K. (1968). The neurogenic scapulo-peroneal syndrome. European Neurology, 1, 257274.

Rowland, L. P., Schotland, D. L., Lovelace, R. E., and Layzer, R. B. (1967). Neurogenic muscular atrophies. In Exploratory Concepts in Muscular Dystrophy and Related Disorders, ed. by A. T. Milhorat, pp. 41-45. Excerpta Medica International Congress Series No. 147, Amsterdam.

Schott, J., Jacobi, M., and Wald, M. A. (1955). Electrocardiographic patterns in the differential diagnosis of progressive muscular dystrophy. American fournal of the Medical Sciences, 229, 517-524.

Schuchmann, L. (1970). Spinal muscular atrophy of the scapuloperoneal-type. Zeitschrift für Kinderheilkunde, 109, 118-123.

Shoji, H., Sugita, K., Furukawa, T., Igata, A., and Tsukagoshi, H. (1970). Proximal spinal muscular atrophy (Kugelberg-Welander disease and its variant) with sex-linked recessive inheritance. Clinical Neurology (Tokyo), 10, 256-262.

Skyring, A. and McKusick, V. A. (1961). Clinical, genetic and electrocardiographic studies in childhood muscular dystrophy. American fournal of the Medical Sciences, 242, 534-547.

Smith, J. B. and Patel, A. (1965). The Wohlfart-KugelbergWelander disease. Neurology, 15, 469-473.

Spira, R. (1963). Neurogenic, familial, girdle type muscular atrophy. Confinia Neurologica, 23, 245-255.

Spira, R. (1967). A family with Kugelberg-Welander disease: electromyographic findings in subclinical cases. Confinia Neurologica, 28, 423-431.

Spiro, A. J., Fogelson, M. H., and Goldberg, A. C. (1967). Micro=cephaly and mental subnormality in chronic progressive spinal muscular atrophy of childhood. Developmental Medicine ande Child Neurology, 9, 594-601.

Thieffry, S., Arthuis, M., and Bargeton, E. (1955). Quarante cas de maladie de Werdnig-Hoffmann avec onze examens anatomiques. Revue Neurologique, 93, 621-644.

Thomson, J. and Bruce, A. (1893). A case of progressive muscular atrophy in a child with a spinal lesion. Edinburgh Hospital Reports, 1, 361-383.

Trillet, M., Girard, P. F., Schott, B., Ramel, P., and Woehrle, R. (1970). La paralysie bulbo-pontine chronique progressive avec surdité. A propos d'une observation clinique. Presse Médicale, 78, 129-130.

Tsukagoshi, H., Nakanishi, L., Kondo, K., and Tsubaki, T. (1965). Hereditary proximal neurogenic muscular atrophy in adult. Archives of Neurology, 12, 597-603.

Tsukagoshi, H., Sugita, H., Furukawa, T., Tsubaki, T., and Ono, E. (1966). Kugelberg-Welander syndrome with dominant inheritance. Archives of Neurology, 14, 378-381.

Tsukagoshi, H., Shoji, H., and Furukawa, T. (1970). Proximal neurogenic muscular atrophy in adolescence and adulthood with $\mathrm{X}$-linked recessive inheritance. Neurology, 20, 1188-1193.

Tsukagoshi, H., Takasu, T., Yoshida, M., and Toyokura, Y. (1969). A family with scapuloperoneal muscular atrophy. Clinical Neuro$\log y$ (Tokyo), 9, 511-517.

Van Laere, J. (1966). Paralysie bulbo-pontine chronique progressive familiale avec surdité. Un cas de syndrome de KlippelTrenaunay dans la même fratrie. Problèmes diagnostiques et génétiques. Revue Neurologique, 115, 289-295.

Verger, P., Vital, C., Guillard, J. M., Eschapasse, P., and Le Pennec, J. J. (1969). Les formes 'intermediaires' de l'amyotrophie spinale infantile (a propos de six observations nouvelles). Pédiatrie, 24, 131-143.

Walton, J. N. (1956). Amyotonia congenita, a follow-up study. Lancet, 1, 1023-1028.

Walton, J. N. (1957). The limp child. Fournal of Neurology, Neurosurgery and Psychiatry, 20, 144-154. 
Walton, J. N. (1970). Some pitfalls in the diagnosis of muscular disorders. In Proceedings of the 2nd International Congress of Neuro-Muscular Pathology, Marseille. (In press.)

Werdnig, G. (1891). Zwei frühinfantile hereditäre Fälle von progressiver Muskelatrophie unter dem Bilde der Dystrophie, aber auf neurotischer Grundlage. Archiv für Psychiatrie und Nervenkrankheiten, 22, 437-481.

Werdnig, G. (1894). Die frühinfantile progressive spinale Amyotrophie. Archiv für Psychiatrie und Nervenkrankheiten, 26, 706744.

Wiesendanger, M. (1962). Über die hereditäre nuerogene, proximale Amyotrophie (Kugelberg-Welander). Archiv der fulius Klaus-Stiftung für Vererbungsforschung, Soziolanthropologie, und Rassenhygiene, 37, 147-174.

Wohlfart, G., Fex, J., and Eliasson, S. (1955). Hereditary proximal spinal muscular atrophy - a clinical entity simulating progressive muscular dystrophy. Acta Psychiatrica Neurologica, 30, 395-406.

Woratz, G. (1964). Neurale Muskelatrophie mit dominantem $\mathrm{X}$-chromosomalem Erbgang. Abhandlungen der deutschen Akademie der Wissenschaften zu Berlin, Klasse für Medizin, 2, 1-99. Quoted by Becker (1966) and Pratt (1967).

Zellweger, H. and McCormick, W. F. (1968). Scapuloperoneal dystrophy and scapuloperoneal atrophy. Helvetica Paediatrica Acta, 23, 643-649.

Zellweger, H., Schneider, H., and Schuldt, D. R. (1969a). A new genetic variant of spinal muscular atrophy. Neurology, 19, 865869.

Zellweger, H., Schneider, H. J., Schuldt, D. R., and Mergner, W. (1969b). Heritable spinal muscular atrophies. Helvetica Paediatrica Acta, 24, 92-105. 